\title{
Flats Outdoor Space as a Vital Social Place
}

\author{
Azhan Abdul Aziz ${ }^{1}$, Abdullah Sani Ahmad ${ }^{1}$, Tajul Edrus Nordin ${ }^{2}$ \\ ${ }^{1}$ Faculty of Built Environment, Universiti Teknologi Malaysia, Skudai \\ ${ }^{2}$ Faculty of Architecture, Planning \& Surveying, Universiti Teknologi MARA Perak, Bandar Seri Iskandar \\ azhanaziz@gmail.com
}

\begin{abstract}
Minimum dwelling space of low-cost walk-up flats forces life to spill outdoors involving daily mundane activities affecting neighborhood social vitality. In design, this affordance of such 'marginal' outdoor space has been neglected. Using data derived from systematic observations in various low cost walk up flats, this paper explores the use of these outdoor near home spaces and found that they support various domestic, social and retreat activities generating liveliness in the otherwise barren low cost environment. Potentials for social encounters and casual surveillance were partially affected by flats configurations.
\end{abstract}

Keywords: building layout, near home space, social interaction

eISSN 2514-751X @ 2017 The Authors. Published for AMER ABRA by e-International Publishing House, Ltd., UK. This is an open-access article under the CC BY-NC-ND license (http://creativecommons.org/licenses/by-ncnd/4.0/). Peer-review under responsibility of AMER (Association of Malaysian Environment-Behaviour Researchers), ABRA (Association of Behavioural Researchers on Asians) and cE-Bs (Centre for EnvironmentBehaviour Studies), Faculty of Architecture, Planning \& Surveying, Universiti Teknologi MARA, Malaysia. https://doi.org/10.21834/aje-bs.v2i5.221 


\subsection{Introduction}

In Malaysia, the provision of urban housing for the low income group has become increasingly critical as urbanization expands, rural-urban migration escalates, and cost of living enlarges the proportion of urban poor (Agus, 1990). Development of low cost housing has been an important social and political agenda in Malaysian development policies. In the Eighth five-yearly Malaysia Plan, 200,513 low cost housing units were built. Another 165,400 units of low cost were targeted to be built between 2006 and 2010, within the Ninth Malaysia Plan (Government of Malaysia, 2005). Zero squatter policy targeted by some states also contributes to growing demands. In the urban fringes of major cities, walk-up flats were popular due to the relatively high density and the lower construction, land and maintenance costs. Layout variations of such housing have been regulated by economic efficiency and constraints of building standard. Concerns over the livability of flats grow as studies on residential preference and satisfaction repeatedly point to the importance of such low cost housing design to be more sensitive to the social implications of physical planning (Paim \& Yahaya, 2004; A. Salleh \& Yusof, 2006; A. G. Salleh, 2008). Emphases have been put on benefits of common open space and neighborhood amenities. However, such emphases overlook the social potentials of outdoors near home spaces and disregard human-environment transactional processes to achieve satisfaction.

This paper reports on the field observations in four of the most common low cost flats types to explore the use of outdoor near home space as important social setting for the residents. It aims to find any association between flats configurations and the patterns of daily residential uses. By focusing on the behavioral observation, this study would contribute to the appreciation of human environment transactional relationships while uncovering the affordances of such basic low cost configuration for residents' material and social appropriations.

\subsection{Literature Review}

Growing international literatures point to the concerns over low socialization among urban residents and suggest rising individualistic and home centeredness of urban domestic life. Nonetheless, other non-western studies lend only mild support for such findings. Reviews of studies on neighboring and residential social life in Hong Kong and Singapore for example showed that constrains in private space and limited access to public space alternatively transform outdoor areas in residential blocks into vibrant social spaces (Forrest, Grange \& Ngai-Ming, 2002). With proper spatial configuration, a sense of social vibrancy, similar to vernacular living, could be nurtured even in high rise living (Bay, 2004). This is even more critical in low income housing where local social support is still valued.

Areas around the residential block serve as a suitable unit for analysis of residential social life. The micro-ecology of such environment involves the everyday mundane activities generating repeated exposure and encounters at the block level vital for residents' social 
and physical attachment (Taylor, 1997). Local social contacts in daily routine are still significant factors of the richness and vitality of social life despite advancement in information and communications technology and private transport (Argent, 2008; Holland, Clark, Katz \& Peace, 2007). Insufficient dwelling spaces also render the outdoor housing area as important extension of the homes for other functional and social activities (Abu-Ghazzeh, 1999; Klaufus, 2000; Steemers \& Steane, 2004) and as potentials for relationship opportunities, and investment of care and attachment (Cloutier-Fisher \& Harvey, 2008; Mee, 2009). They also influence how one perceives, uses and engages in the social environment (Coolen, 2006). Recurring informal meetings, encounters and the resulting familiarity are also argued to generate collective actions of a community referred to as social climate (Adriaanse, 2007). It is displayed in the individual actions in public, residents' contribution to the 'curb appeal', collective arrangements and participation. The resulting familiarity provides grounds for collective action and expanding personal contacts as a source of social support, particularly important in low income communities.

Outdoor near home space in low cost housing is heavily subjected to appropriations, through which people adapt to and make a space as a place they could call home (de Haan, 2005; Feldman \& Stall, 1994). It is a means to achieve congruence with the physical and social environment so that satisfaction could be attained (Kaplan, 1983). Appropriations not only allow residents to realize their ideal picture of a home but also serve as tools to recreate an image of the nostalgic living environment or ideal community. Engaging with neighbors and personalizing the exterior spaces, strengthen the resident's nostalgic feeling of vernacular living (Bay, 2004; de Haan, 2005). In housing areas, the house and the exterior spaces are interconnected physically and socially. Appropriation is also a means of territorial control. By using the space, people display their territorial domain. In return they serve others as informal social control fostering a sense of safety and security (Burchfield, 2009). Thus it is important to pay attention to the near home space to understand how favorable local social climate develops and is sustained.

The role of physical environment in affording interactions cannot be undermined in improving residents' attachments to housing (Brandon, Hirt \& Cameron, 2008; Huang, 2006). Afeeling of belonging accumulates around repeated encounters with physical and social surroundings, and daily shared experiences (Hargreaves, 2004, 53; Williams, 2005). Even different street layouts afford different outdoor activities that facilitate attachment to the neighborhood (B. B. Brown \& Werner, 1985; Sauter \& Huettenmoser, 2008). Presence of functional spaces complementing the dwelling units, such as interactional and communal spaces, and other related social facilities (Huang, 2006; Kang, 2006; Sirgy \& Cornwell, 2002) impacts the residents' quality of life (Sirgy \& Cornwell, 2002; Sugiyama \& Thompson, 2005). Having neighborhood environment of these positive potentials encourages one to invest time, social and physical resources to generate meaningful attachment to the community, and local social support (Boyce, 2006; Mee, 2009). Architectural characteristics of the dwellings (S. Brown, et al., 2009), appropriated outdoor space enclosures (Al-Homoud \& 
Tassinary, 2004), and outdoor semi-private spaces (Williams, 2005) also affect social interaction and social support among neighbors. For children, different configurations flats afford different outdoor space appropriation and experiences (Azhan Abdul Aziz \& Ahmad, 2010; Azhan Abdul Aziz \& Ahmad, 2011). Abu Ghazzeh (1999) found that near home space often serves as a substitute for large open spaces as they contribute little to resident's good neighborhood perception and evaluation. People value opportunities to walk around and sit in small groups near their homes which more effectively lead to friendship formation and maintenance. In high rise housing, forecourts become not only encounter spaces where greeting are exchanged but also space for engaging more social activities such as social and cultural gatherings (Bay, 2004).

\subsection{Methodology}

\section{Site Selection}

The study was conducted in Johor Bahru, the state capital of Johor located at the southern tip of Peninsular Malaysia. In 2000, Johor recorded the highest number of low cost units built $(134,775)$ followed by Selangor (131,330 units).

Table 1: Summary of selected sites

\begin{tabular}{|c|c|c|c|c|}
\hline & Flats1 & Flats 2 & Flats 3 & Flats 4 \\
\hline \multicolumn{5}{|l|}{ Building configuration } \\
\hline Circulation type & Open corridor & Double internal & $\begin{array}{l}\text { Single internal } \\
\text { corridor }\end{array}$ & $\begin{array}{l}\text { Glustered around } \\
\text { staircase }\end{array}$ \\
\hline Year of cocupation & $1997 / 8$ & $2002 / 4$ & 2004 & 2000 \\
\hline No. of units & 480 & 480 & 480 & 476 \\
\hline Site area & $6.01 \mathrm{ac} .(2.43 \mathrm{ha})$. & $5.09 \mathrm{ac} .(2.06 \mathrm{ha})$. & 5.87 ac. (2.37 ha.) & 5.24 ac. (2.12 ha.) \\
\hline Density & 80 units per acre & 94 units per acre & 82 units per acre & 90.8 units per acre \\
\hline No. of blocks & 6 & 6 & 6 & 6 \\
\hline No. of floors & 5 & 5 & 5 & 5 \\
\hline No. of units per floor & 16 & 20 & 20 & 4 \\
\hline Ground covered comman court & No & Yes & Yes & Yes \\
\hline $\begin{array}{l}\% \text { of majority ethnic group } \\
\text { Racial components }\end{array}$ & $86.0 \%$ & $84.8 \%$ & $93.7 \%$ & $76.1 \%$ \\
\hline
\end{tabular}

In the Ninth Malaysia Plan, Johor expects to build the highest number of low cost 
housing at 91,500 units after Selangor (Government of Malaysia, 2005). Johor Bahru district alone has more than 60 sites of low cost flats. Up to the third quarter of 2009 , the district has a sum of 85,396 low cost units constituting $50.8 \%$ of all low cost units in the state. $46 \%$ of them $(39,276$ units) are flats (NAPIC, 2009). After the third quarter, additional 4,663 units of flats were expected. Flats are thus important form of housing in urban area of Johor Bahru. Four low cost housing sites were purposively sampled to control for building height, housing age, racial heterogeneity and population size (Table 1). They represent four of the most common walk-up flats configurations (Long, 2007). Flats 1 is a u-shaped single- loaded open air corridor type forming an open court occupied by parking. Flats 2 has two rows of units facing one another and served by a double internal corridors with a central vertical air well. In Flats 4, similar configuration is employed except that the units are served by a single internal corridor. Flats 3 , as the most recent flats type, contain clusters of units organized around staircases and minimal corridor space. All areas contain six blocks five-storey flats. However, the ground levels of Flats 2, 3 and 4 are occupied by covered common courts.

\section{Systematic observations}

Systematic behavioral observations were conducted using behavioral checklist with maps. Age, ethnicity and gender of the residents and their behaviors were recorded and mapped by two observers following predetermined routes. Reliability tests show $88.5 \%$ agreement on the behavioral constructs observed and $94.9 \%$ agreement on the event type. 16 observations were conducted in each site covering four hours in the morning (9am to $12 \mathrm{pm}$ ) and another four in the afternoon ( $3 \mathrm{pm}$ to $6 \mathrm{pm}$ ) on both weekends and weekdays. The times were sampled based on the most active times identified in the preceding pilot studies. The average duration for each observation is 30 minutes and distributed into 8 to 10 minutes for each block at each hour of observation.

Behaviors observed are categorized as social and non-social activities (Sullivan, Kuo \& Depooter, 2004). Non-social ones are further defined as domestic and retreat activities. Domestic activity category involves routine household activities including those related to the functioning of the family (e.g. cloth lining, looking after the children and putting out rubbish) and care towards the dwelling exterior space (e.g. watering plants, sweeping and cleaning). Retreat activity category comprises all outdoor solitude activities people engage in as a means of fulfilling personal needs to get away and connotes the feeling of safety and comfort to be alone outside. The most common ones include sitting, relaxing or havingnap alone outside, playing alone and watching the surrounding. Social activity encompasses all group activities including interaction with other fellow residents prolonged group behaviors such as sitting in groups and having a conversation, and playing in groups, and brief gestural or verbal greetings. 


\subsection{Results and Discussions}

\section{Who: gender and age}

Overall, 3,374 people were observed including children (33.37\%), teenagers $(14.29 \%)$ and adults $(52.34 \%)$. Women were active users of outdoor space registering $30.05 \%$ of all people recorded, engaging particularly in domestic activities and socializing. This is followed by male children (21.83\%). Female dominance around the near home space in all four housing sites suggests a similar population of housewives in selected sites with working husbands. Their presence increases the percentage of adult socializing. Social activity observed mostly involved male children (27.41\%) and female adults (23.78\%). Domestic activity is dominated by adult women (42.95\%). More than half of all retreat activity is shared by male children $(27.60 \%)$ and adult $(25.87 \%)$. Teenagers use less of the local outdoor spaces as they tend to be away from their parents and hang out with friends in distant places (Clark \& Uzzell, 2002). Elderly residents were the least observed which might be attributed to the medium range of housing age selected.

\section{What: domestic, social and retreat}

Of all 2,982 events observed, 2,951 events (98.96\%) were identified to fit the behavioral categories for analysis. Flats 1 recorded the highest number of activity events amounting to $31 \%$ of all recorded events (Figure 1), followed by Flats $3(27 \%)$, Flats $2(22 \%)$ and Flats 3 $(20 \%)$. Assuming a comparable population size and social homogeneity as controlled by the site selection, this suggests possible design factor in the variation of activity affordances in outdoor near home spaces. Table 2 illustrates the different uses of the near home spaces. Activities in public spaces, such as lingering, chatting, sitting, watching and playing (Sauter \& Huettenmoser, 2008), were found to be as common in low cost residential area. Of the total observed events, social activity constitutes $41.89 \%$ followed by domestic activity $(36.04 \%)$ and retreat activity (20.72\%). Contrary to other studies (for example Huang (2006)), the findings in the present research indicate that housing areas close to homes are fertile social spaces, at least in the low cost residential environment. Presence of people outside the units is highly dominated by social activities such as adults chatting in group (24.67\%) and children playing (12.74\%). Increase in social activity, particularly groups playing, also adds events to watch as people engage in the outdoor when there are things to do and events or view to watch (Zhang \& Lawson, 2009). For example, increase in social events is accompanied by more retreat activities (Figure 1). In addition, the nature of open corridor with wide surrounding street view, particularly in Flats 1 , might also contribute to the increase in retreat activity. 


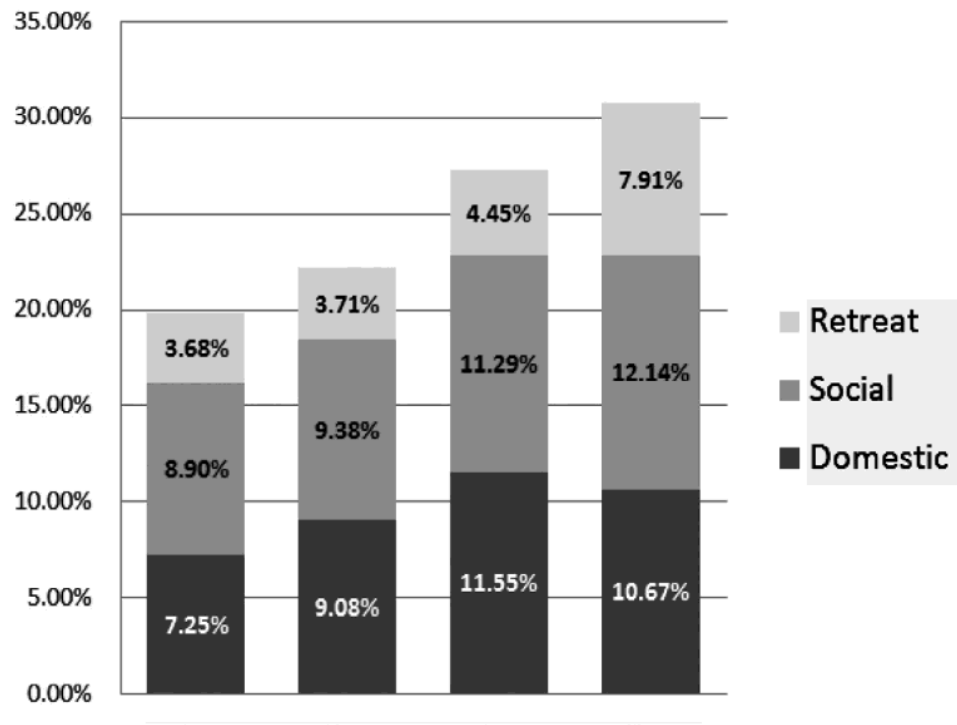

Flat 4

Flat 2

Flat 3

Flat 1

Figure 1: Overall activity distribution

Table 2: Outdoor activity components

\begin{tabular}{|c|c|c|c|c|c|c|c|c|}
\hline Domestic Activity & $\begin{array}{l}\% \text { within } \\
\text { category }\end{array}$ & \% overall & Retreat Activity & $\begin{array}{l}\text { \% within } \\
\text { category }\end{array}$ & $\%$ overall & Social Activity & $\begin{array}{l}\text { \% within } \\
\text { category }\end{array}$ & $\%$ overall \\
\hline Cloth Lining & $33.82 \%$ & $1235 \%$ & Watching events/views & $44.20 \%$ & $928 \%$ & Talking/Conversing & $58.10 \%$ & $24.67 \%$ \\
\hline Tending to Kids & $19.71 \%$ & $7.20 \%$ & Playing Alone & $24.54 \%$ & $5.15 \%$ & Playing in Group & $30.01 \%$ & $1274 \%$ \\
\hline Tending to Vehicle & $13.91 \%$ & $5.08 \%$ & On Phone/Computer & $10.25 \%$ & $2.15 \%$ & Briel encounter/greeting & $7.15 \%$ & $3.04 \%$ \\
\hline Tending to House & $12.96 \%$ & $4.73 \%$ & Relaxing/sitting & $8.40 \%$ & $1.76 \%$ & Watching/sitting in Group & $2.24 \%$ & $0.95 \%$ \\
\hline Patronizing Hawkers & $9.18 \%$ & $3.35 \%$ & Smoking & $6.39 \%$ & $1.34 \%$ & Door to door visit & $2.00 \%$ & $0.85 \%$ \\
\hline Pulting Out Rubbish & $2.71 \%$ & $0.99 \%$ & Reading/Writing & $3.36 \%$ & $0.71 \%$ & Other & $0.50 \%$ & $0.21 \%$ \\
\hline Tending to Plants & $1.93 \%$ & $0.71 \%$ & Ealing/Drinking & $2.02 \%$ & $0.42 \%$ & & & \\
\hline Check mail & $1.35 \%$ & $0.49 \%$ & Other & $0.84 \%$ & $0.18 \%$ & & & \\
\hline Other & $4.44 \%$ & $1.62 \%$ & & & & & & \\
\hline Total & $100.00 \%$ & $36.04 \%$ & Total & $100.00 \%$ & $20.72 \%$ & Total & $100.00 \%$ & $41.89 \%$ \\
\hline
\end{tabular}


Where: level and location
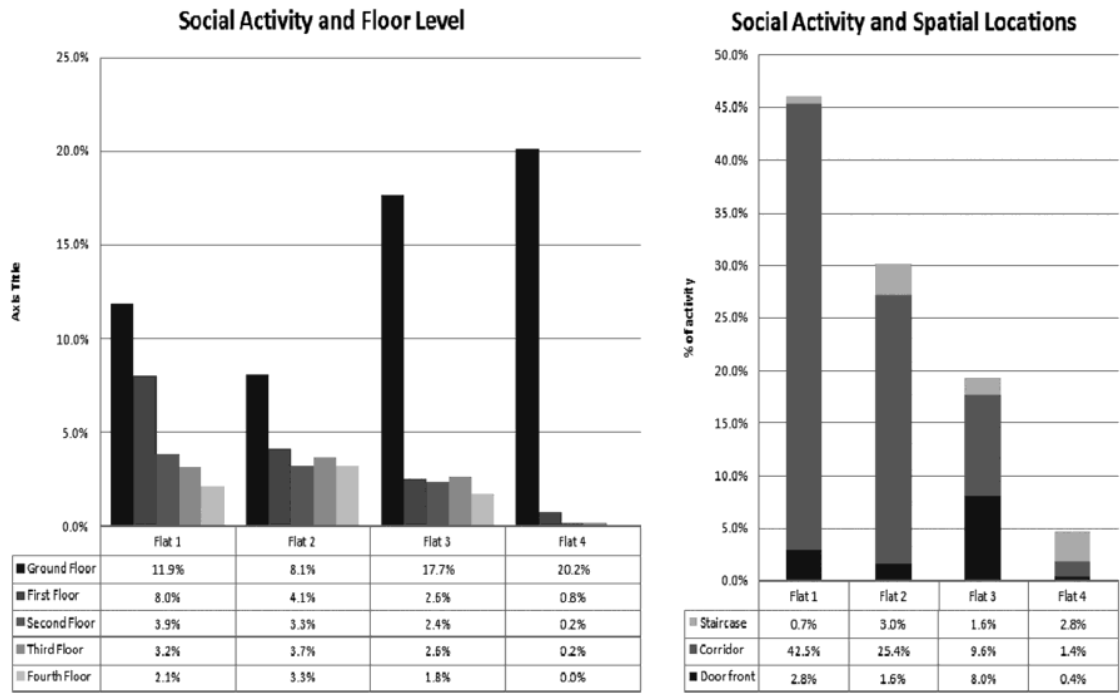

Figure 2: Distribution of social activity

More than half of all activities in flats (55.8\%) were observed in the blocks and near the homes, including in the corridors, and the staircases. All three activity categories observed generally decrease as the floor level rises. However a closer look at the upper floors indicates pattern of variations across the different housing configurations. Due to the low number of observed activities in Flats 4, only observations from Flats 1, Flats 2 and Flats 3 having different types of corridor are being considered in this analysis. The effect of height on social activity observed in the upper floors is only significant in Flats 1 (X2 $=11.324, p<$ 0.05). As we go up the levels, the frequency of observed social activity reduces. In the other two flats, different height does not seem to significantly affect the differences in social interaction observed. The internal corridor and narrow air-well configurations downplay the effects of floor differences. However, while comparing between floors in each housing, configuration only significantly affect the frequency of observed social activity at the first floor level $(X 2=7.822, p<0.05)$. This shows that providing open corridors could increase the possibility of social activity observed, but only significantly at the first floor. The higher the level of open corridor housing the less possibility of observed social activity. 
Table 3: Analysis of major social activity

\begin{tabular}{|c|c|c|c|c|c|c|c|}
\hline Group conversation & Flats 1 & Flats 2 & Flats 3 & Flats 4 & TOTAL & $x^{2}$ & $p$ \\
\hline Frequency & & & & & & & \\
\hline Street, Parking \& Perimeter & $10.1 \% \quad 3.2 \%$ & $8.1 \% \quad 1.5 \%$ & $38.8 \% \quad 11.7 \%$ & $29.2 \% \quad 5.6 \%$ & $22.0 \%$ & 10.862 & $0.0125 * *$ \\
\hline Covered Common Court & $0.0 \% \quad 0.0 \%$ & $19.8 \% \quad 3.7 \%$ & $35.3 \% \quad 10.6 \%$ & $60.7 \% \quad 117 \%$ & $25.9 \%$ & 4.339 & 0.1142 \\
\hline \multirow[t]{3}{*}{ Corridor } & $89.9 \% \quad 28.9 \%$ & $72.1 \% \quad 13.4 \%$ & $25.9 \% \quad 7.8 \%$ & $10.1 \% \quad 1.9 \%$ & $52.1 \%$ & 31.017 & $0.0000^{* * *}$ \\
\hline & $1000 \% \quad 32.2 \%$ & $1000 \% 18.6 \%$ & $100.0 \% 300 \%$ & $1000 \% 192 \%$ & $100.0 \%$ & 6.058 & 0.1088 \\
\hline & & Corridor of Flats 2 & Corridor of Flats 3 & Corridor of Flats 4 & & & \\
\hline \multirow[t]{4}{*}{ t-Test between corridors } & & t-value $\quad p$ & t-value $\quad \vec{p}$ & t-value $p$ & & & \\
\hline & Corridor of Flats 1 & $3.5310 .0005=2$ & $\overline{11.0350 .0000}$ & $\overline{12.1620 .0000}=2$ & & & \\
\hline & Corridor of Flats 2 & & $6.7920 .0000 * 4$ & $8.3510 .0000^{\text {*** }}$ & & & \\
\hline & Corridor of Flats $\mathrm{J}$ & & & $2.9240 .0038 * \approx$ & & & \\
\hline Brief encounters & Flats 1 & Flats 2 & Flats 3 & Flats 4 & TOTAL & $x^{2}$ & $p$ \\
\hline Frequency & & & & & & & \\
\hline Street, Parking \& Perimeter & $12.0 \% \quad 3.1 \%$ & $0.0 \% \quad 0.0 \%$ & $19.5 \% \quad 8.3 \%$ & $9.1 \% \quad 1.0 \%$ & $12.5 \%$ & 6.834 & 0.0328 ** \\
\hline Covered Common Court & $0.0 \% \quad 0.0 \%$ & $10.5 \% \quad 2.1 \%$ & $12.2 \% \quad 5.2 \%$ & $63.6 \% \quad 7.3 \%$ & $14.6 \%$ & 2.812 & 0.2451 \\
\hline \multirow[t]{3}{*}{ Corridor } & $88.0 \% \quad 22.9 \%$ & $89.5 \% \quad 17.7 \%$ & $68.3 \% \quad 29.2 \%$ & $27.3 \% \quad 3.1 \%$ & $72.9 \%$ & 20.376 & $0.0001^{* * *}$ \\
\hline & $100.0 \% \quad 26.0 \%$ & $1000 \% \quad 19.8 \%$ & $100.0 \% \quad 42.7 \%$ & $100.0 \% \quad 115 \%$ & $100.0 \%$ & 20.943 & $0.0001^{* * * *}$ \\
\hline & & Corridor of Flats 2 & Corridor of Flats 3 & Corridor of Flats 4 & & & \\
\hline \multirow[t]{4}{*}{$t$-Test between corridors } & & t-value & $t$-value & t-walue & & & \\
\hline & Corrider of Flats 1 & $0.155 \quad 0.8773$ & $1.812 \quad 0.0747$ & 3.6420 .0009 & & & \\
\hline & Corridor of Flats 2 & & $1.764 \quad 0.0829$ & 9.4830 .0016 *** & & & \\
\hline & Corridor of Flats 3 & & & $2.4610 .0174 * *$ & & & \\
\hline
\end{tabular}

$* p<0.05, *+p<0.005$

For the internal corridor type, social activity is observed more in the double corridors (Flats 2) than in the single corridor. The floor level did not show any significant difference. As found in social activity, floor height has similar effect on retreat activity within each housing site. Height only plays significant role in affecting frequency of observed retreat activity in Flats 1 . However the different configurations still influence the activity significantly up to the second levels (first floor: $X^{2}=11.791, p<0.005$; second floor: $X^{2}=6.762, p<$ 0.05 ). The significance gradually decreases as the floor rises (third floor: $X^{2}=3.561, p=$ 0.1685 ; fourth floor: $X^{2}=1.999, p=0.3681$ ). Open corridor flats maintains as an apt place for retreat, particularly watching the surrounding, because of the street view it offers. The findings reveal that the corridor, being the closest space to homes, remains the most active space for all three activities observed particularly in Flats 1, Flats 2 and Flats 3 . This suggests the importance of adjacency of activities to home range. Parents favor kids to play near the homes while adults prefer to be close to homes where they are able to control the amount of interactions and encounters.

Statistical examinations reveal that the different flats configurations significantly relate to the differences in the amount of the activities observed. In order to examine the corridor configuration effects on the major social activity and retreat activity, t-tests were performed between activities at the corridor levels (Table 3). The results indicate that prolonged social interactions (e.g. people sitting in groups having conversation) vary 
significantly with all different flats layout even at alpha level of 0.005 . Open corridor configuration of Flats 1 significantly affords more potential for occurrences of such events. Larger corridor areas contribute to higher observed interactions. However, for brief encounters, only comparisons with Flats 4 indicate significant differences. Brief encounters seem to be only significantly affected by number of units per floor rather than configuration.

\subsection{Conclusions}

Outdoor near home spaces of flats are important arenas for social, domestic and retreat activities. These routines activities, as the sources of attachment and sense of place, could be important evidence for positive social climate or vitality of a neighborhood environment. The extent and spatial distribution of such usages depend partly upon the building configurations as notable variations are found between the different types as well as the amount and proportion of those observed activities. A particular type of configuration does differ to another in its affordance levels and the ability for the residents to appropriate them materially and socially. Social encounters and ability for people to be outside watching particularly differentiate the different low cost flats sites. These are significant activities which were found to be prerequisite for social engagement and social participation and the building and reinforcement of social relation. These social potentials of environmental design for facilitating such effects offer valuable research prospect. With such knowledge, the potentials for social integration through design are closer to homes than any planning policy might expect.

\section{Acknowledgement}

This study is supported by the Fundamental Research Grant Scheme(VOT: 78656), Universiti Teknologi Malaysia, and Universiti Teknologi MARAPerak. The authors wish to acknowledge the invaluable assistance of officers in relevant departments of NAPIC, Majlis Bandaraya Johor Bahru (MBJB), Majlis Perbandaran Johor Bahru Tengah (MPJBT) and Majlis Perbandaran Pasir Gudang (MPPG).

\section{References}

Abdul Aziz, A. \& Ahmad, A. S. (2010). Flats layouts and children outdoor activities. Paper presented at the ASIA / Pacific Conference on Environment-Behaviour Studies (AicE-Bs 2010), Kuching.

Abu-Ghazzeh, T. (1999). Housing layout, social interaction, and the place of contact in Abu-Nuseir, Jordan. Journal of Environmental Psychology, 19(1), 41-73. 
Adriaanse, C. (2007). The utility of the 'social climate' concept in understanding urban neighbourhood-life: A theoretical approach and initial empirical evidence Delft, Netherland: OTB Research Institute for Housing and Mobility Studies

Agus, M. (1990). Urbanization and low-income housing in Malaysia: impact on the urban Malays. Journal of Population and Social Studies, 2(2), 205-221, 242-203.

Al-Homoud, M. \& Tassinary, L. G. (2004). Social interactions at the neighborhood-level as a function of external space enclosure. Journal of Architectural and Planning Research, 21(1), 10-23.

Argent, N. (2008). Perceived density, social interaction and morale in New South Wales rural communities. Journal of Rural Studies, 24(3), 245-261.

Bay, J.-H. (2004). Sustainable community and environment in tropical Singapore high-rise housing: the case of Bedok Court condominium. Environmental Design, 8(3-4).

Boyce, I. (2006). Neighbourliness and Privacy on a Low Income Estate. Sociological Research Online, 11(3).

Brandon, A., Hirt, J. B. \& Cameron, T. (2008). Where You Live Influences Who You Know: Differences in Student Interaction Based on Residence Hall Design. [Article]. Journal of College \& University Student Housing, 35, 62-79.

Brown, B. B. \& Werner, C. M. (1985). Social Cohesiveness, Territoriality, and Holiday Decorations: The Influence of Cul-de-Sacs. Environment and Behavior, 17(5), 539-565.

Brown, S., Mason, C., Lombard, J., Martinez, F., Plater-Zyberk, E. \& Spokane, A., et al. (2009). The Relationship of Built Environment to Perceived Social Support and Psychological Distress in Hispanic Elders: The Role of Eyes on the Street". The Journals of Gerontology Series B: Psychological Sciences and Social Sciences.

Burchfield, K. (2009). Attachment as a source of informal social control in urban neighborhoods. Journal of Criminal Justice.

Clark, C. \& Uzzell, D. L. (2002). The affordances of the home, neighbourhood, school and town centre for adolescents. Journal of Environmental Psychology, 22(1-2), 95-108.

Cloutier-Fisher, D. \& Harvey, J. (2008). Home beyond the house: Experiences of place in an evolving retirement community. Journal of Environmental Psychology.

Coolen, H. (2006). The meaning of dwellings: an ecological perspective. Housing, Theory and Society, 23(4), 185201.

de Haan, H. (2005). Social and Material Appropriation of Neighborhood Space: Collective Space and Resistance in a Dutch Urban Community. Paper presented at the 'Doing, thinking, feeling home: the mental geography of residential environments' International Conference.

Feldman, R. M. \& Stall, S. (1994). The politics of space appropriation: a case study of women's struggles for homeplace in Chicago public housing. In I. Altman \& A. Churchman (Eds.), Women and the Environment (pp. 167).

Forrest, R., Grange, A. \& Ngai-Ming, Y. (2002). Neighbourhood in a high rise, high density city: some observations on contemporary Hong Kong. The Sociological Review, 50(2), 215-240. 
Government of Malaysia (2005). Ninth Malaysia Plan, 2006-2010.

Hargreaves, A. (2004). Building communities of place: Habitual movement around significant places. Journal of Housing and the Built Environment, 19(1), 49-65.

Holland, C., Clark, A., Katz, J. \& Peace, S. (2007). Social interactions in urban public places. Bristol, UK: Joseph Rowntree Foundation.

Huang, S. (2006). A study of outdoor interactional spaces in high-rise housing. Landscape and Urban Planning, 78(3), 193-204.

Kang, B. (2006). Effects of open spaces on the interpersonal level of resident social capital: a comparative case study ofurbanneighborhoodsin Guangzhou, China. Unpublished PhD, Texas A\& M University.

Kaplan, S. (1983). A Model of Person-Environment Compatibility. Environment and Behavior, 15(3), 311-332.

Klaufus, C. (2000). Dwelling as representation: Values of architecture in an Ecuadorian squatter settlement. Journal of Housing and the Built Environment, 15, 341-365.

Long, L. Y. (2007). Sejarah perkembangan perumahan pangsa awam tanpa lif Kuala Lumpur dari tahun 1957 ke 1988. Unpublished Master, Universiti Teknologi Malaysia, Skudai.

Mee, K. (2009). A space to care, a space of care: public housing, belonging, and care in inner Newcastle, Australia. Environment and Planning A, 41,842-858.

NAPIC (2009). Residential Property Stock Report Q3 2009. Putrajaya: Pusat Maklumat Harta Tanah Negara.

Paim, L. \& Yahaya, N. (Eds.). (2004). Kesejahteraan Isi Rumah Johor Darul Takzim. Serdang: Penerbit UPM.

Salleh, A. \& Yusof, N. (2006). Residential Satisfaction in Low-Cost Housing In Malaysia. Pulau Pinang: Universiti Sains Malaysia.

Salleh, A. G. (2008). Neighbourhood Factors in Private Low-cost Housing in Malaysia. Habitat International, $1(002), 1-9$.

Sauter, D. \& Huettenmoser, M. (2008). Livable streets and social inclusion. Urban Design International, 13(2), 6779.

Sirgy, M. \& Cornwell, T.(2002). How Neighborhood FeaturesAffect Quality of Life. Social Indicators Research, 59(1), 79114.

Steemers, K. \& Steane, M. (2004). Environmental Diversity in Architecture: Spon Press. Sugiyama, T. \& Thompson, C. (2005). Environmental Support for Outdoor Activities and Older People's Quality of Life. Journal of Housing for the Elderly, 19(3/4), 167.

Sullivan, W. C., Kuo, F. E. \& Depooter, S. F. (2004). The Fruit of Urban Nature: Vital Neighborhood Spaces. Environment and Behavior, 36(5), 678-700.

Taylor, R. B. (1997). Social Order and Disorder of Street Blocks and Neighborhoods: Ecology, Microecology, and the Systemic Model of Social Disorganization. Journal of Research in Crime and Delinquency, 34(1),113-155. 
Abdul Aziz, A., et.al. / Asian Journal of Environmen-Behaviour Studies, ajE-Bs, 2(5) Oct / Dec 2017 (p.39-51)

Williams, J. (2005). Designing Neighbourhoods for Social Interaction: The Case of Cohousing. Journal of Urban Design, 10(2), 195 - 227.

Zhang, W. \& Lawson, G. (2009). Meeting and greeting: Activities in public outdoor spaces outside high-density urban residential communities. Urban Design International, 14(4), 207-214. 